\title{
EMPIRICAL ANALYSIS OF AGRICULTURAL DEVELOPMENT FINANCING AND THE WAYS TO IMPROVE AGRIBUSINESS MANAGEMENT
}

\author{
George Abuselidze ${ }^{1}$, Doctor of Economics/ Professor; Irma Chkhaidze², Doctor of
}

Economics/ Professor and Nanuli Makharadze ${ }^{3}$, Academic Doctor of Business and

Management / Professor

\section{1, 2, 3 Batumi Shota Rustaveli State University}

\begin{abstract}
Uncertain future under the conditions of COVID-19 has changed population 's behaviour, views, daily rhythm without coercion in real practice. Global world suddenly found himself in the midst of an economic recession. All branches of sectoral structure of economy have actually become a hostage of the healthcare. It's begun not only the strengthen of population's interests on the development of the domestic economy, but it's begun the reverse migration of the village immigrated population from town to the village too. In such conditions, the introduction of integrated management practice of agribusiness plays a great role in the country, which should ensure the effectiveness of the natural resources management. In the article, it's been reviewed one of the priority branch in the sectoral structure of Georgian economy - problems and perspectives of rural and agricultural development, the effectiveness of sector funding has been assessed. In particular, what kind of influence international and state projects, funded in agro-sphere, have on rural development, raising the level of welfare, growth the volume of products, produced in agriculture and at the development level of the national economy of the country. The goal of the research is to learn, analyse and evaluate the effectiveness of the state programs, funded and implemented for the development of agribusiness, features of project management. According to economic and statistical analysis and synthesis methods of the research, it's been determined how was able the projects, funded for the development of rural entrepreneurship to develop the sector, also how personal and public welfare was created by them. The results of the research have revealed the influence of COVID-19 on the development of family farming and new strategies for the development of agribusiness have been set. In the near future, this process can be used as a basis of maximum utilization and use the agricultural potential.
\end{abstract}

Key words: agribusiness, agricultural finance, agricultural policy, finance in rural economies, investments.

JEL code: Q13, Q14, Q18, R51

\section{Introduction}

One of the challenges of 21 st century is environmental protection, which is considered as a contributing factor of human's living environment and there`s no prospect for the development of the world without it. In order to create favourable environment and improve it, scientists have been conducting different kinds of researches, new fields are being created, which are mainly directed to the improvement of both, environmental conditions and climate and to the raising of people's standard of living as well. Accordingly, it can be said that the development of agriculture irreversible character. Under the market relations, where scientific and technological progress is going, the restriction problem of the natural resources is growing. In such conditions, the actuality of the role of rural economy and agriculture increases and it gets a great importance, which can be shown by creating new workplaces (jobs) and by achieving socio-economic efficiency.

At modern stage, the countries around the world have to carry out such complex problem as the improvement of food system is, due to the global challenges, existing in the world: the growth population of the planet, scarcity of the resources and COVID-19. Accordingly, the maximum utilization of agricultural potential of Georgia and using it for special purpose has a great importance. It's vital for country 's economy to ensure food security problems. The practice of the countries shows that $70-80 \%$ of the world food is produced by family farming, $40 \%$ of the world's population is involved in it. And they are the ones, who manage $70-80 \%$ of agricultural lands (Agroface, 2020). Due to the actuality of the work, the purpose

1 Corresponding author. Ninoshvili street 35. Batumi, 6010, Georgia. E-mail address: george.abuselidze@bsu.edu.ge

2 Ninoshvili street 35. Batumi, 6010, Georgia

3 Ninoshvili street 35. Batumi, 6010, Georgia 
of the research envisages to determine that finances for development of agribusiness, got from the state budget by the entities and finances, attracted with the international programs, was practically used in economic terms or it was limited to eradicate short-term social problems.

Based on the purpose of the research, the following tasks were identified: to determine the effectiveness of the expenditure of financial resources allocated from the state budget for agricultural development on the basis of empirical research; To determine the productivity of EU-funded rural and agricultural development programs based on empirical and systematic analysis.

\section{Literature review}

Georgian scientists and economists, who were interested in agricultural sector and farming over the years: O. Vashakidze (1996), N. Chitanava (1993), Z. Elizbarashvili (1993), D. Katamadze (2020) and others recognize that the improvement and development of family farming (peasant farming) is one of the strategic direction of our country's agricultural development, what will promote not only the rational use of the land, but the growth of productivity of the family members and hired labor as well as the continuity of the reproduction process. Also, it should be noted of both, Georgian and foreign scientists and economists: A. Favareto (2016), L. S. Grossman (1998), P. O' Hara (1998), Angus et al., (2009), D. Glover, K. Kusterer (2016), C. Schader et al., (2013), M. Schneider (2015), Lai et al., (2018), Richards and Arima (2018) - controversial opinion about separation of peasant, farming, family farming, that was the reason, why they could not reach a single scientific agreement. For example, O. Vashakidze and L. Khaburdzania (1996) thought that: peasant farming is the simplest form, mainly, natural type of farming, which is characterized with low production (marketability), it's based on scientific-technical progress abd requires manual work.

N. Chitanava (1993) and Z. Elizbarishvili (1993) think that, peasant and farming should be considered as a single form of peasant farming and household is considered as homestead farming. Also, it's noted that peasant farming, as a more intensive form of farming, preferably produces commodity products. i.e. products are mainly created for the market, unlike homestead farming, the product of which is mainly consumed by the family and only the surplus products run to the market . If we take into account the dynamism of Georgia 's agriculture and its hard prediction, the formation of a strategic model of agricultural enterprises is connected with difficulty. That's why, it should be based on the concept of strategic management of agribusiness. According to Katamadze et al., (2020), Barnard et al., (2016), Polakovic et al., (2018), Mariyono (2019), Yami et al., (2019), N. M. Dennis (2019), Dentoni et al., (2020), R. Griffin (2021), and others, the level of agribusiness management is reflected in management skills of generating and realizing competitive advantages of agrarian enterprises.

Except for theoretical and methodological basis of the work, the scientific works of Georgian and foreign scientists are: data of the National Statistics Office of Georgia (2020), Ministry of Environmental Protection and agriculture of Georgia (2021), Ministry of Economy and Sustainable Development of Georgia (2020), legislative and sub-legislative acts, resolutions, decrees and etc., researches of governmental and nongovernmental international organizations, acting in the country, studies - conducted by the authors. Economic-statistical, analysis and synthesis methods are used in the work to conduct the research process properly.

\section{Research results and discussion}

Not only natural, but non-common and inefficient realization of acquired and relative advantages can be named as a hindering factor of agriculture, one of the priority fields of sectoral structure of Georgian 
economy. The issue is still actual, when the object of the research and review is to reveal the problems, existing in family farming, to determine their underlying causes and to identify the possibilities for selfdevelopment. The development of agriculture is mainly connected to the green economy and accordingly, it ensures the improvement of social-economic situation. In this case, the attention can be focused on organic agriculture, which in accordance with Codex Alimentarius (international food standard) is such management system of unified production, which refuses to use such synthetic materials as toxic chemicals, pesticides, fertilizers and other substances are, which may have a negative influence on the environment and human's health. Thus, development of organic agriculture and accordingly, the production made in such farm, which is recognized as an organic product, the demand on it is increasing rapidly worldwide (Figure 1).

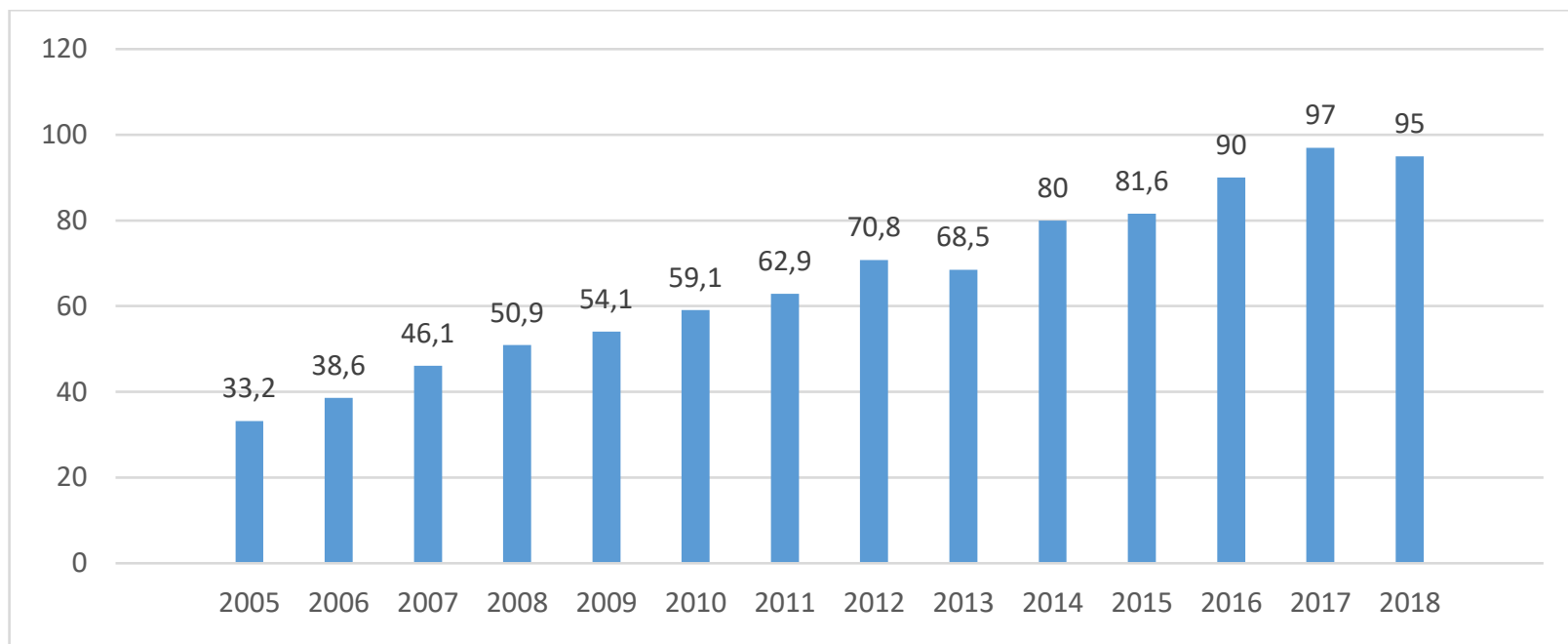

\section{Source: author's calculations based on Statista}

Fig. 1. Worldwide sales of organic food (2005-2018)

Due to its unique conditions, Georgia has a good prospect to become a producer and exporter of organic product. The main thing for this is the effective use of the amounts, allocated from state budget and effectiveness for implementation of state or international programs (Abuselidze, Mamuladze, 2020). Trends of agricultural financing (Figure 2) shows that its share in budget payment is average $2 \%$ and budget of 2020 envisaged the financing of the sector with 293 million Gel, what is $2 \%$ of the expenses. 


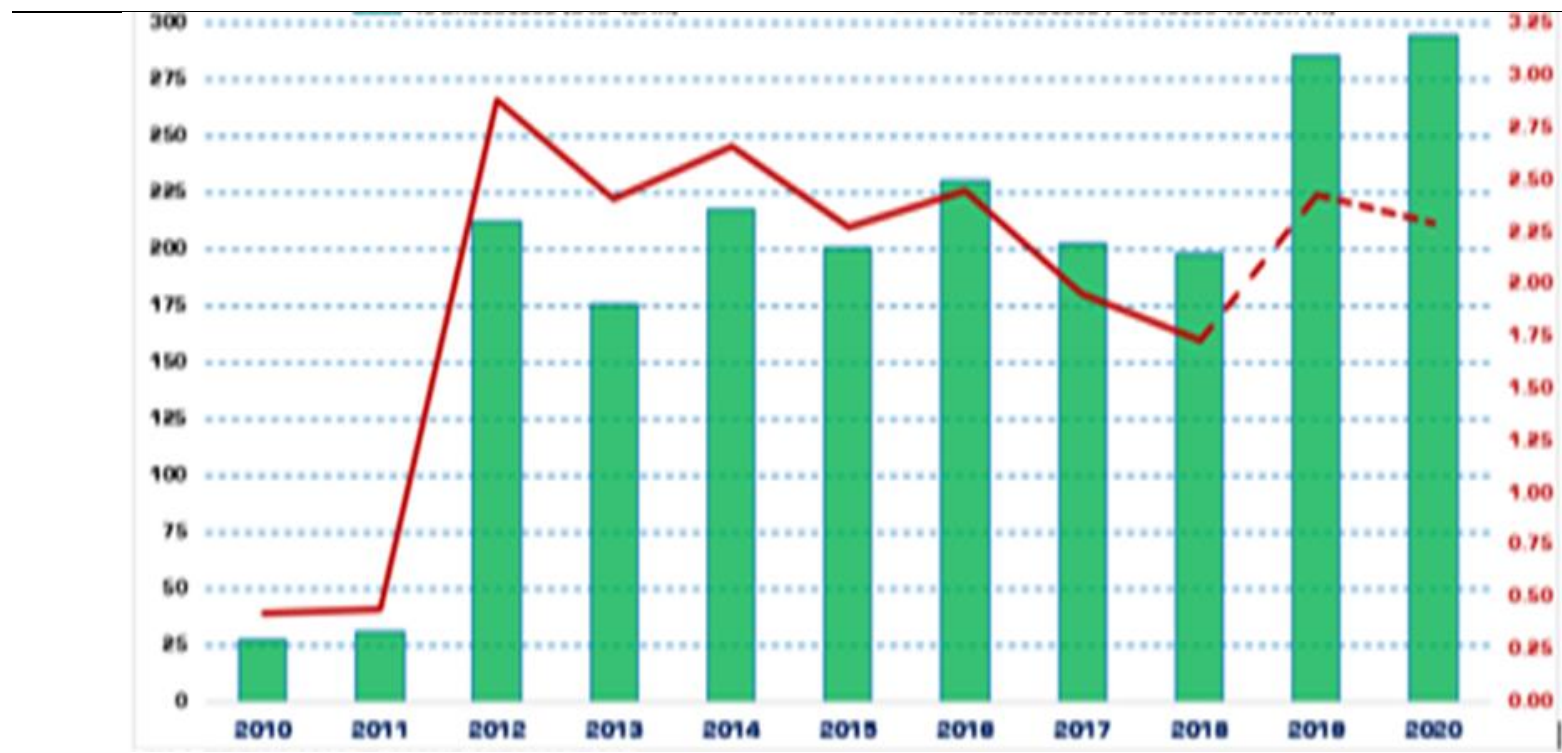

Source: author's calculations based on Ministry of Environmental Protection and agriculture of Georgia

Fig. 2. Financing of agriculture (million GEL; \%)

Despite of increasing the finances of agriculture, its real growth rate was decreasing every year, in 2017 - in spite of increase, it was decreased with $3.82 \%$. In 2018, it was increased with only $0.72 \%$ (Figure 3). While the share of agriculture in word economy is: in China - 8.6 \%, in Czech Republic - $2.5 \%$, in Denmark $-0.9 \%$, in Estonia - $2.6 \%$, in Finland - $2.7 \%$, in France - $1.6 \%$, in German - $0.6 \%$, in Ireland - $1 \%$, in Italy - $2.1 \%$, in Luxembourg - $0.3 \%$, in the Netherlands $-1.8 \%$, in Norway $-2.4 \%$, in Saudi Arabia $-2.7 \%$, in Spain $-2.8 \%$, in the United Kingdom - $0.6 \%$.

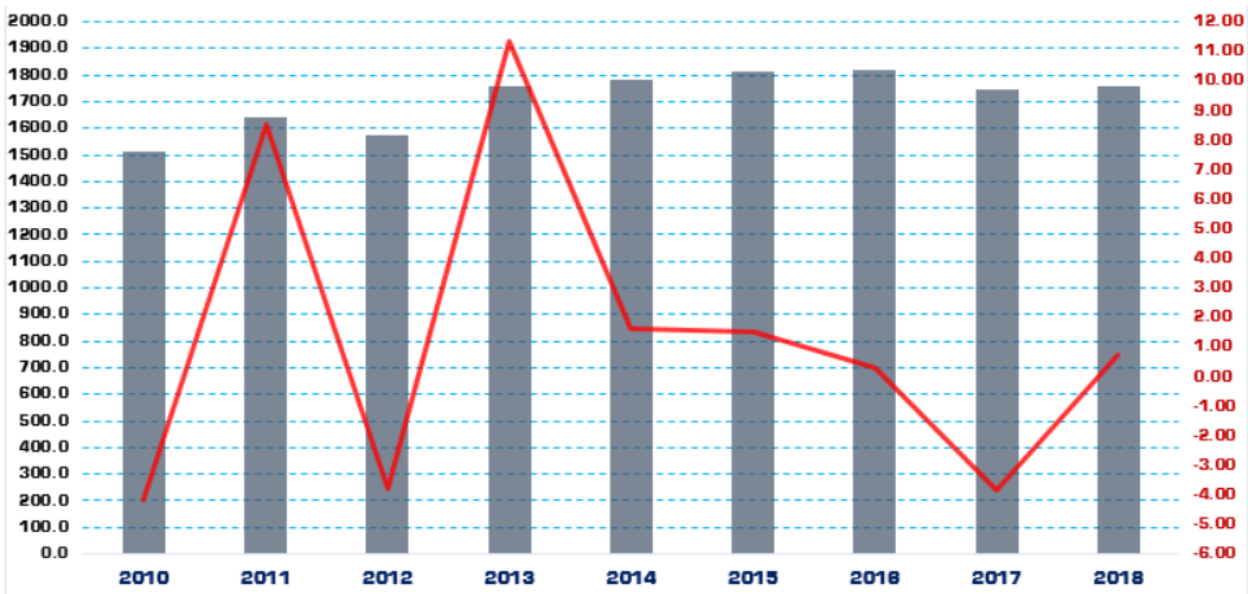

Source: author's calculations based on National statistics office of Georgia

Fig. 3. Real growth of agriculture and GDP sector (million GEL; \%)

Analysis of current practical processes has shown that the development level of agriculture, the increase of the volume of the produced products and raising of the quality level of the service is impossible by selfdevelopment of $98 \%$ family farming, existing in Georgia and by the utilization on average 1.14 hectares of land, existing in their ownership, which shows the land shortage and hinders the ability to develop largescale agricultural production and take advantage of the scale effect (Business Media, 2020; Transparency International - Georgia, 2020). While the average value of the agricultural land (cropland) used by one farming is: in the United States - 190.2 ha., in Germany - 30.3 ha., in the countries of European Union 17.4 ha., on average, in Russia - 42 ha., in Ukraine - 22 ha., in Kyrgyzstan - 22 ha., in Kazakhstan 44.4 ha., in Belarus - 20 ha., in Uzbekistan - 10 ha., in Armenia - 1.5 ha., in Azerbaijan - 4 ha., in Tajikistan - 45 ha., in Turkmenistan - 1 ha., in Moldova - 3 ha., in the Baltic countries - 24.5 ha. And the 
dimensions of agricultural lands (cropland), used by farming are as follows: $0.2 \%$ of farming uses from 1 to 5 hectares agricultural land (cropland) in the United States, in Germany - 31.7 \%, in the countries of European Union - 56.4 \%, in Georgia - 98 \%. 60.4 \% of farming uses from 5 to 50 hectares agricultural land (cropland) in the United States, in Germany - 55.7\%, in the countries of European Union - 35.7\%, in Georgia $-1.5 \%$. More than 50 hectares of agricultural land is used by $39.4 \%$ farms in the USA, in Germany - $12.6 \%$, in the countries of European Union - on average $7.9 \%$ and in Georgia - only $0.1 \%$ (Jakhaia, 2018).

Analysis of the results of the research revealed that the food, produced in family farming, is mainly used to meet the basic needs of the family. This can be based on the data of National Statistics office regarding the years 2007-2019, according to which, the share of food expenditures in the total consumer expenses of household in 2007, 2008, 2009 consisted of $55.9 \%, 54.3 \%, 51.3 \%$, in 2010 it decreased with $9.3 \%$ compared with 2007 and it was $46.6 \%$; in 2017 it decreased by $7.2 \%$ compared with 2011 and it consisted of $41.5 \%$ and in 2019, it increased by $1.6 \%$ compared with 2017 and it was $43.0 \%$ (Figure 4 ).

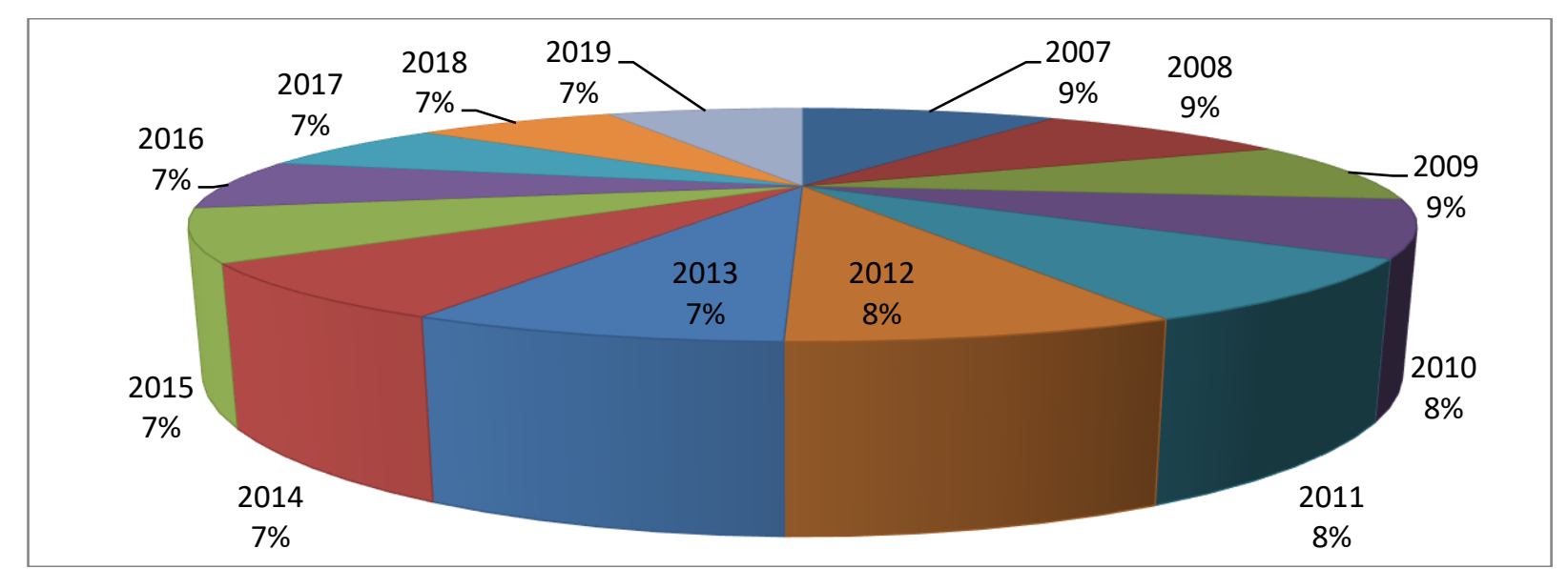

Source: author's calculations based on National statistics office of Georgia

Fig. 4. The share of expenditure of food

Since 2013, a strategic document for agricultural development has been developed in Georgia and about 500 projects in the direction of development/rehabilitation of agriculture, environmental protection, tourism, education and rural infrastructure have been carried out, which were funded by European Union (it was used by approximately more than 300000 beneficiaries), with the business initiative of rural development, funded under these projects, more than 1000 local family were employed and living conditions for more than 10000 rural population were improved. Despite of the fact that, since 2013 the state has set goals in the development of agriculture by implementing the mentioned project, global pandemic announced worldwide in 2020 has had the greatest impact on the country's economy (Abuselidze, Mamaladze, 2020) and it has had some negative influence on agriculture as well.

The current situation in Georgia shows that, due to this situation, the development of agriculture has become more priority for the state and the government makes a number of recommendations to support it, as in the current period under the COVID-19 crisis, the economic activity has been slowed down around the world and including in Georgia except for agriculture and food, which creates the products, required for living in the current conditions. The above-mentioned support means to allocate 2-billion Gel to stimulate the economy, including agribusiness sector and farmers, in order farmers will be able to buy the equipment with cheap and interest-free loans, tax benefits and special projects. One of such support is full co-financing of 6-month interest rate by the state on loans from 5000 to $100000 \mathrm{GEL}$ in order to increase assess to 
finance for the farmers, what is free one-year money for farmers to grow one-year products. The given support will somehow eliminate many problems, caused by pandemic (Rural Development Agency, 2021).

The European Union (EU), the Ministry of Environmental protection and Agriculture of Georgia and the Food and Agriculture Organization of the United Nations (FAO) have awarded 2.2 million GEL to 50 beneficiaries for agricultural grants ${ }^{4}$ under ENPARD III in Georgia for uninterrupted development of agricultural activity and for supporting food production and food security under the pandemic conditions, which will be used to buy agricultural equipment (machinery) and to arrange the greenhouse (hothouse). ENPARD program (the volume of its initiative exceeds 5 million GEL in total), which provides 40-60\% co-financing of the total value of the investments, gives even more farmers the opportunity to benefit from this financial support on the next stage. In response to COVID-19, another 9 million grant program was announced by European Union and United Nations Development Program, which will help non-farm start-ups and growing enterprises. Under the current epidemiological situation, when the current crisis in the country hinders the development of the agriculture even more, a number of activities, carried out within ENPARD are the most timely step for supporting the agriculture at present. Among them, there's new grant competition, announced within the framework of one of the project "This is Tsalka": "New challenges - new opportunities" with the grant amount - 3.000 Euro and 3 projects were chosen, which will promote effective management of the crisis, caused as a result of coronavirus and it 'II make a quick reaction on these new challenges, before which is faced Georgia as a result of pandemic, caused by the spread of corona virus (European Union for Georgia, 2020).

As it seems, the role and support of the program was revealed even more on the background of epidemiological situation, when the development of agriculture required additional funds in the form of grants most of all. Since 2013, ENPARD program together with the government, ensured to solve the basic problems, which were related to the financial resources and hindered the mobilization of adequate funds for agricultural development, which will ultimately become the basis for promoting the introduction of a green economy. Finally, we conclude that ENPARD is one of the most important programs in terms of supporting the rural and agriculture development, which allows the state to develop such priority sector for the government as agriculture is, by sharing international and European practices and to ensure the reduction of economic inequality, existing between urban and rural areas. Accordingly, implementation of the mentioned program, which includes the implementation of various projects under ENPARD-3, it can be considered as a step forward for the development of green economy by the state. At the same time, its implementation will increase the rural employment and accordingly, it will improve the living standards, develop and strengthen of the rural economy, increase the competitiveness of agriculture, improve environmental protection and take appropriate steps in order to achieve sustainable management of natural resources, which is the main tool for achieving the sustainable development and a prerequisite for the introduction of a green economy.

International cooperation and financial measures, carried out by the country, plays a great role in the implementation of green economy in financing. In this regard, in terms of allocating of so called "green finances", is important to develop such instruments as they 're: Green Investment Fund, Green Bonds, as well as Green Credits, which will be directed to the purpose of green financing and etc., which provides the allocation of some funds to finance relevant technology projects and fields in the sectors of green economy (Abuselidze, Beridze, 2018; Abuselidze, Slobodianyk, 2019; Davydenko et al., 2017; 2019). 
Under the green finances, state project "Preferential Agro Credit", which implies the issuance of lowinterest loan on persons, involved in agriculture by the commercial banks and financial institutions (Abuselidze, 2021), participating in the project. On the one hand, the implementation of the mentioned project helps the country to develop such priority direction as agriculture is and on the other hand, it ensures to develop and implement a supporting project for the development of green economy by the state. The growth of the total portfolio of agro credits can be considered as an indicator of the success of the preferential agro-credit project (Figure 5).

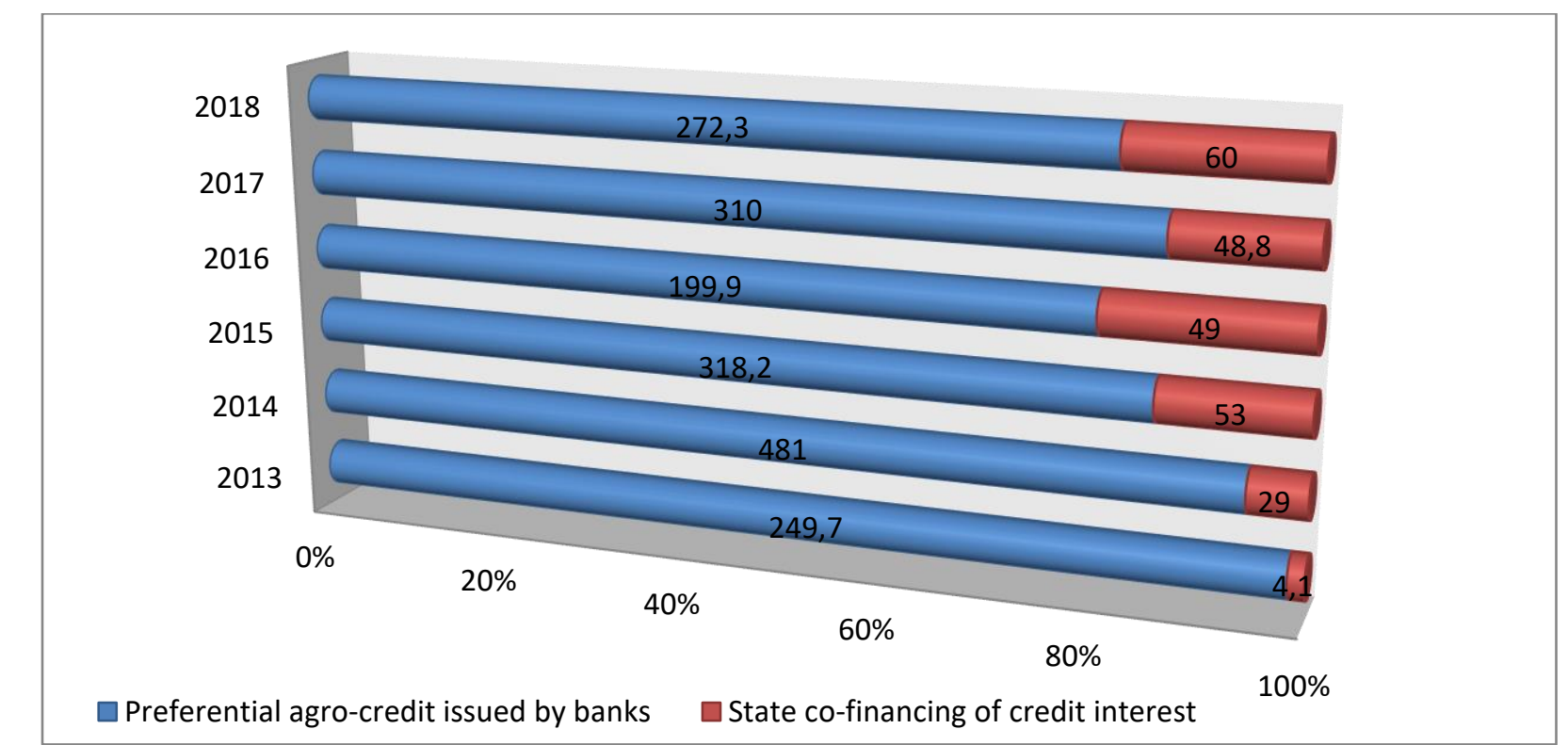

Source: author's calculations based on Ministry of Environmental Protection and agriculture of Georgia

Fig. 5. The value of credits, issued in accordance with 2013-2018 years (million GEL)

As diagram shows, 1.8 billion Gel agro-credit was issued from 2013 year to 2018 year, which was used for working capital and fixed assets and 20 million GEL for leasing. For beneficiaries, who wanted credit for leasing, for working capital or fixed assets, from their fixed interest rate, which is from $12 \%$ to $21 \%$ and depending on the amount of loan, they had to pay from $3 \%$ to $9 \%$ of the loan interest rate. As we see, the role of co-financing in agro-preferential credit is great, which stimulates and promotes the development of existing sector even more. 


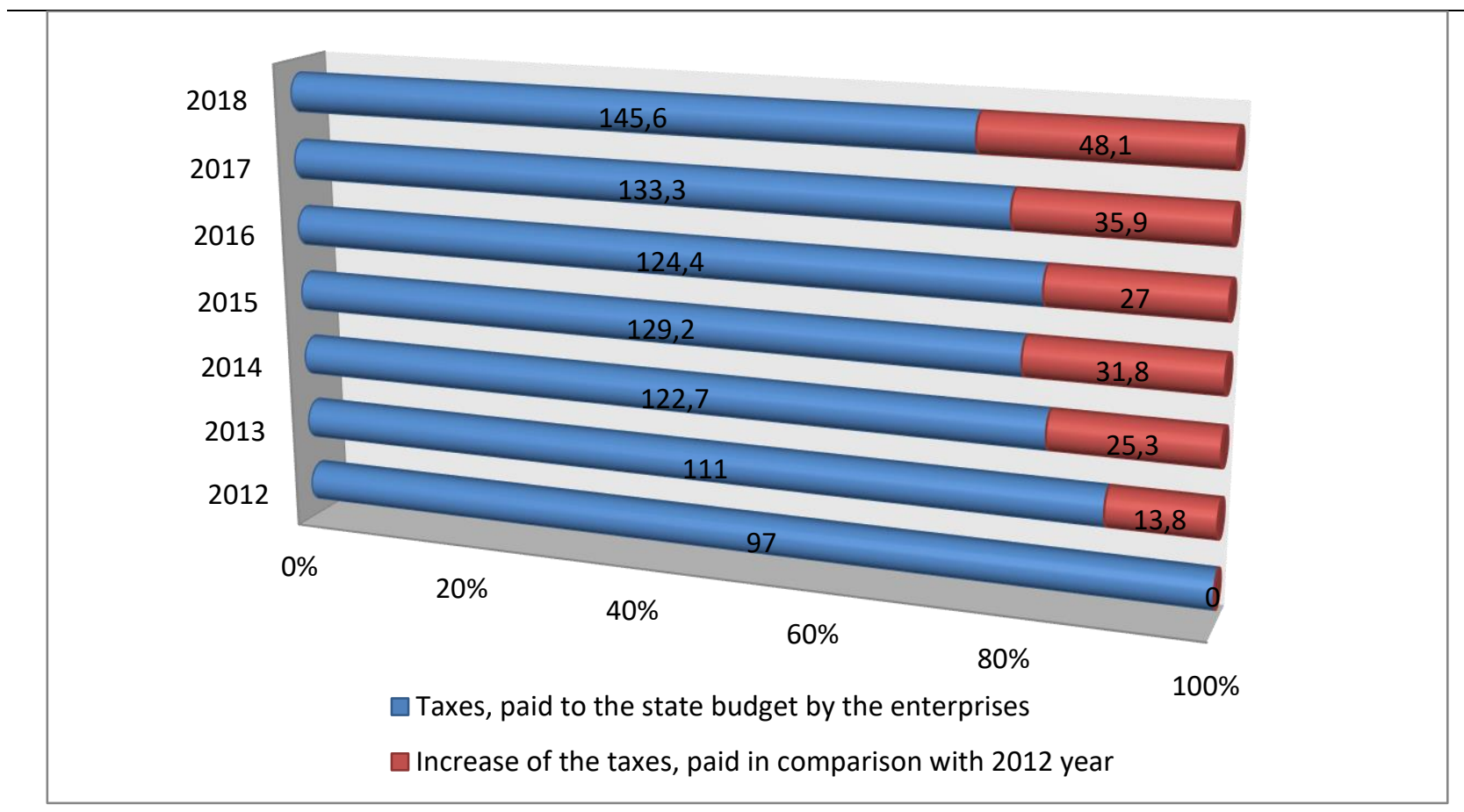

Source: author's calculations based on Ministry of Environmental Protection and agriculture of Georgia

Fig. 6. Taxes, paid to the state budget by the beneficiary enterprises of preferential agro-credit project (2010-2018. Beneficiaries registered as taxpayers only)

In order to measure project effectiveness, it would be appropriate to compare the cost of products, created by the beneficiary companies of the project in relation to the total added value created by the country, which would give us a more accurate picture of the project's effectiveness. However, the project is not analysed in this regard and the only data, that's counted and summarized by the beneficiary enterprises of "preferential agro-credit" project are the taxes, paid to the state budget (Figure 6).

In order to measure the effectiveness of the program, the annual taxes, paid by the beneficiaries was compared to the period, when the program was not launched or 2012 year. according to the statistics, in 2012 year, the taxes, paid by the enterprises, registered as a tax payer in 2012 year was 97420387 GEL. In 2013-2018 years, the taxes paid by the beneficiaries of the "Preferential Agro Credit" project exceeded with 181935303 GEL to the data of 2012 year. At the same period, 244445796 GEL was spent for co-financing of the loan interest of the program beneficiaries by the state. Therefore, the amount, spent by the state is more than the surplus of the taxes, paid by the beneficiary companies in the mentioned years, which was spend in favour of farmers.

The research, conducted for assessment of preferential agro-credit project proves the effectiveness of the state program. From 2013 year to 2018 year, 12600 new workplaces are created (the number of employees is actually higher, as given data are obtained only according to the indicators of the beneficiaries registered as taxpayers), whose gross income in 2018 year 2.36 times exceeds to the gross income of agricultural enterprises of 2012 year (it's increased with $136 \%$ ). The rural population is depended on the income, got from agribusiness (Katamadze et al., 2020). Economic benefit, got through the mentioned project, contributed the development of agriculture and promotional conditions for the given sector were introduced, which responds to the practice of introducing a green economy.

Research was also focused on finding ways of additional income for family farming and determining the directions of effectiveness of spending (Abuselidze, Surmanidze, 2020). The analysis of the research results showed that family farming will develop their defined field in agriculture on the basis of natural and acquired 
(acquired through financing or own funds) advantages and receive small economic benefits from the sale of the produced crop / product.

The rural and agricultural development in Georgia provides the sustainable development of the country, which is revealed with economic, social and ecological benefit. Economic benefit can be: growth of the gross domestic product (GDP), caused due to increased production of ecological products, diversification of the product or service, improvement of economic risks management and reduction of the risks, innovative growth by using modern ecological technologies and others. The effectiveness of using the natural resources is reviewed as an ecological benefit and increased living conditions, improvement of incomes and/or quality of life, especially for poor population, creation of additional workplaces, equalization of living standards inequality, protection of the green policy and environment - is reviewed as a social benefit.

\section{Conclusions}

The existence of a deep and comprehensive free trade area with the European Union has a positive effect on the prospects of world market integration, on the existence of a global supply network and it creates a significant basis for the growth of direct foreign investments (Abuselidze, 2019). All the above mentioned promotes the introduction of new technologies and know-how, stimulates the production of competitive local organic products and creates work places, forms trading system, compatible with the market of European Union and stimulates the economic growth. However, it's also necessary to activate an effective financial and economic mechanism for agribusiness management, which contributes the growth of the production of organic products; The formation of a multi-sectoral economy should establish market relations, characterized for agribusiness; A state strategy for the consolidation of agricultural lands should be developed. Targeted budget funding should be increased for the development of agrarian sector, which will firstly be used to increase land productivity, land-reclamation and for the construction of the relevant agro-industrial infrastructure.

\section{Bibliography}

1. Abuselidze, G., Beridze, L. (2018). The Role of Alternative Investments in the Development of Capital Markets: in Terms of the Transformation of Georgia with the EU. Proceedings of the 4th International Conference on European Integration (ICEI), pp. 29-41.

2. Abuselidze, G. (2019). European Integration of Georgia and Financial-Economic Condition: Achievements and Challenges. European Journal of Sustainable Development, 8(1), pp. 53-68. DOI:10.14207/ejsd.2019.v8n1p53

3. Abuselidze, G., Slobodianyk, A. (2019). Investment of the Financial Instruments and their Influence on the Exchange Stock Market Development. 20th International Scientific Conference Economic Science for Rural Development 2019, No. 52. pp. 203-210. DOI:10.22616/ESRD.2019.124

4. Abuselidze, G., Mamuladze, L. (2020). The Peculiarities of the Budgetary Policy of Georgia and the Directions of Improvement in Association with EU. Proceedings of the Innovative Economic Symposium 2019 - Potential of Eurasian Economic Union (IES2019). SHS Web of Conferences, 73, 01001. DOI:10.1051/shsconf/20207301001

5. Abuselidze, G., Surmanidze, M. (2020). Analysis of Performance Efficiency of Legal Entities of Public Law and Non-Profit Legal Entities under the Central and Local Government Bodies: in Terms of the Transformation of Georgia with the EU. Proceedings of the 5th International Conference on European Integration 2020, pp. 23-35. DOI: $10.31490 / 9788024844565$

6. Abuselidze, G., Mamaladze, L. (2020). The Impact of the COVID-19 Outbreak on the Socio-Economic Issues of the Black Sea Region Countries. Lecture Notes in Computer Science, 12253, pp. 453-467. Springer, Cham. DOI: $10.1007 / 978-3-030-58814-4 \_32$

7. Abuselidze, G. (2021). The Impact of Banking Competition on Economic Growth and Financial Stability: An Empirical Investigation. European Journal of Sustainable Development, 10(1), pp. 203-220. DOI:10.14207/ejsd.2021.v10n1p203

8. Agroface. (2020). The Role of Family Farming in the Agricultural Sector. Retrieved: https://agroface.ge/news/f00cc85f-44d2-4cd1-9125-7a5a53b022ee. Access: 04.03.2021.

9. Angus, A., Burgess, P. J., Morris, J., \& Lingard, J. (2009). Agriculture and Land Use: Demand for and supply of agricultural commodities, characteristics of the farming and food industries, and implications for land use in the UK. Land Use Policy, 26, S230-S242. DOI:10.1016/j.landusepol.2009.09.020

10. Barnard, F. L., Foltz, J., Yeager, E. A. (2016). Agribusiness Management. Routledge. 
11. Business Media (2020). Changes Have Been Made in the Program "Introduce the Future". Retrieved: https://bm.ge/ka/article/programashi-danerge-momavali-cvlilebebi-shevida/42553. Access: 05.03.2021.

12. Chitanava, N. (1993). Market Economy and Problems of the Development of Agro-industrial Complex, publication "Georgia", p. 75.

13. Davydenko, N., Skryphyk, H. (2017). Evaluation Methods of Investment Attractiveness of Ukrainian Agricultural Enterprises. Baltic Journal of Economic Studies, 3(5), pp. 103-107. DOI:10.30525/22560742/2017-3-5-103-107

14. Davydenko, N., Kliuchka, O., Kulbach, J. (2019). Estimation of Capital of Agro-industrial Enterprises as an Economic Resource. 20th International Scientific Conference Economic Science for Rural Development 2019. DOI: $10.22616 /$ ESRD.2019.128

15. Davydenko, N., Skrypnyk, H., Titenko, Z. (2019). Investment Attractiveness of Agricultural Enterprises. 20th International Scientific Conference Economic Science for Rural Development 2019. DOI: 10.22616/ ESRD.2019.128

16. Dennis, N. M., Ng'ong'a, A., Faith, O. A. (2019). Strategic Management Practices by Beach Management Units in Bondo Sub County, Kenya. International Journal of Academic Research in Business and Social Sciences, 9(10). DOI:10.6007/ijarbss/v9-i10/6484

17. Dentoni, D., Bijman, J., Bossle, M.B., Gondwe, S., Isubikalu, P., Ji, C., Kella, C., Pascucci, S., Royer, A. Vieira, L. (2020). New Organizational Forms in Emerging Economies: bridging the gap between agribusiness management and international development. Journal of Agribusiness in Developing and Emerging Economies, Vol. 10 No. 1, pp. 1-11. DOI:10.1108/JADEE-10-2019-0176

18. Elizbarashvili, Z., (1993). On Peasant Household Modeling, Farming. Economy, 6-7, p. 54.

19. Enterprise Georgia (2021). Retrieved: http://www.enterprisegeorgia.gov.ge/ka. Access: 05.03.2021.

20. European Union for Georgia (2020). ENPARD. Retrieved: http://enpard.ge/ge/about-us/. Access: 08.03.2021.

21. European Union for Georgia (2020). ENPARD. Strengthening of Agricultural Development in Georgia. Retrieved: http://enpard.ge/ge/wp-content/uploads/2015/05/gcp-geo-001-ec-project-highlights.-GEO.pdf. Access: 08.03.21.

22. European Union for Georgia (2020). Food and Agriculture Organization of the United Nations (FAO). Retrieved: http://enpard.ge/ge/the-food-and-agriculture-organization-of-the-united-nations-fao/. Access: 08.03.21.

23. Favareto, A. (2016). Beyond 'Family Farming Versus Agribusiness' Dualism: Unpacking the Complexity of Brazil's Agricultural Model. Retrieved: https://opendocs.ids.ac.uk/opendocs/handle/20.500.12413/12717. Access: 08.03.2021.

24. Forbes (2020). The Share of Agriculture in Georgia and World Economy. Retrieved: https://forbes.ge/sophlismeurneobis-tsili-s/. Access: 03.03.2021.

25. Glover, D., Kusterer, K. (2016). Small Farmers, Big Business: Contract Farming and Rural Development. Springer.

26. Griffin, R. (2021). Fundamentals of Management. Cengage Learning.

27. Grossman, L. S. (1998). The Political Ecology of Bananas: Contract Farming, Peasants, and Agrarian Change in the Eastern Caribbean. University of North Carolina Press.

28. Jakhaia, L. (2018). Economic Problems of Agricultural Sector and Prospects for Overcoming it (on the example of Ajara). Doctoral dissertation (thesis), pg. 51-52. (Batumi State University, 2018). Retrieved: https://www.bsu.edu.ge/text_files/ge_file_9997_1.pdf. Access: 02.03.2021.

29. Katamadze, D., Abuselidze, G., Katamadze, G. (2020). Problem of Agribusiness Management in Georgia. SGEM, 20(5.2), pp. 389-400. DOI:10.5593/sgem2020/5.2/s21.048

30. Lai, J., Olynk Widmar, N. J., Gunderson, M. A., Widmar, D. A., Ortega, D. L. (2018). Prioritization of Farm Success Factors by Commercial Farm Managers. International Food and Agribusiness Management Review, 21(1030-2018-3340), pp. 817-832.

31. Mariyono, J. (2019). Improvement of Economic and Sustainability Performance of Agribusiness Management Using Ecological Technologies in Indonesia. International Journal of Productivity and Performance Management, 69(5), pp. 989-1008. DOI:10.1108/IJPPM-01-2019-0036.

32. Ministry of Environmental Protection and Agriculture of Georgia (2021). Budget, Financial and Material Resources, Labor Remuneration. https://mepa.gov.ge/Ge/FinancialAndMaterialResources/. Access: 08.03.2021

33. National statistics office of Georgia (2020). Food Security. Retrieved: https://www.geostat.ge/en/modules/categories/297/food-security. Access: 08.03.2021.

34. National statistics office of Georgia (2020). Households Income. Retrieved: https://www.geostat.ge/en/modules/categories/50/households-income. Access: 08.03.2021.

35. O'Hara, P. (1998). Partners in Production?: Women, Farm, and Family in Ireland. Berghahn Books.

36. Polakovic, P., Silerova, E., Hennyeyova, K., Slovakova, I. (2018). Business Process Management in Linking Enterprise Information Technology in Companies of Agricultural Sector. Agris on-Line Papers in Economics and Informatics, 10(3), 119-126. DOI:10.7160/aol.2018.100310

37. Projects Georgia (2020). Support to the Agricultural Sector of Georgia (ENPARD III). Retrieved: https://projects.org.ge/view_grant.php?id=315. Access: 08.03.2021.

38. Richards, P., Arima, E. (2018). Capital Surpluses in the Farming Sector and Agricultural Expansion in Brazil. Environmental Research Letters, 13(7), 075011. DOI:10.1088/1748-9326/aace8e

39. Rural Development Agency (2021). Retrieved: http://rda.gov.ge/main. Access: 08.03.2021. 
40. Schader, C., Lampkin, N., Christie, M., Nemecek, T., Gaillard, G., Stolze, M. (2013). Evaluation of costeffectiveness of organic farming support as an agri-environmental measure at Swiss agricultural sector level. Land Use Policy, 31, pp. 196-208. DOI:10.1016/j.landusepol.2012.06.014

41. Schneider, M. (2015). What, then, is a Chinese peasant? Nongmin discourses and agroindustrialization in contemporary China. Agriculture and Human Values, 32(2), pp. 331-346.

42. Statista (2020). Worldwide sales of organic food. Retrieved: https://www.statista.com/search/?q=Worldwide+sales+of+organic+food+\&qKat=search. Access: 08.03.2021.

43. Transparency International - Georgia (2020). Trends, existing in the Agricultural Sector of Georgia in 20122019. Retrieved: https://transparency.ge/ge/post/sakartvelos-soplis-meurneobis-sektorshi-2012-2019-clebshiarsebuli-ziritadi-tendenciebi. Access: 04.03.2021.

44. Vashakidze, O, Lachkebiani, T., (1996). Peasant or Farming. Finances, p. 54.

45. Yami, M., Feleke, S., Abdoulaye, T., Alene, A., Bamba, Z., Manyong, V. (2019). African Rural Youth Engagement in Agribusiness: Achievements, Limitations, and Lessons. Sustainability, 11(1), 185. DOI: $10.3390 /$ su11010185 